\title{
IMPLEMENTASI COSINE SIMILARITY MATCHING DALAM PENENTUAN DOSEN PEMBIMBING TUGAS AKHIR
}

\author{
Loura Yasni, Imam Much Ibnu Subroto*), Sam Farisa Chaerul Haviana \\ Departemen Teknik Informatika, Universitas Islam Sultan Agung, Semarang \\ ${ }^{*}$ Corresponding Author: imam@unissula.ac.id
}

\begin{abstract}
Abstrak
Beberapa faktor yang mempengaruhi keberhasilan penyelesaian Tugas Akhir mahasiswa adalah ketidak sesuaian bidang ilmu dosen dengan tema tugas akhir, beban dosen yang sudah besar dan dosen belum pengalaman melakukan penelitian yang relevan dengan tema tugas akhir mahasiswa. Penelitian ini bertujuan untuk mengimplemnetasikan metode Cosine Similarity dalam penentuan dosen pembimbing tugas akhir supaya mendapatkan proses bimbingan yang optimal. Cosine Similarity adalah metode untuk menghitung similarity (tingkat kesamaan) antar dua buah objek. Pada penelitian ini dihitung tingkat kesamaan antar judul, topik, dan abstrak tugas akhir mahasiswa dibandingkan dengan data dosen pembimbing berupa keahlian dosen pembimbing, tugas akhir yang pernah dibimbing oleh dosen. Kemudian metode Cosine Similsrity akan memnghitung tingkat kesamaan kedua query tersebut. Nilai kemiripan yang tertinggi akan dimunculkan sebagai dosen pembimbing yang direkomendasikan. Metode peneltian yang digunakan adalah metode modified waterfall. Sistem yang telah dibangun merupakan sistem rekomendasi yang dapat membantu koordinator tugas akhir dalam pendistribusian dosen pembimbing tugas akhir. Selain itu, sistem rekomendasi dosen pembimbing tugas akhir dengan menerapkan metode Cosine Similarity membantu mahasiswa mendapatkan dosen pembimbing sesuai dengan tugas akhir yang diajukan.
\end{abstract}

Keyword: Sistem rekomendasi, dosen pembimbing, cosine similarity

\begin{abstract}
This research aims to implement the method of Cosine Similarity in the determination of thesis advisor. Cosine Similarity is a method for calculating similarity between two objects. In this thesis, the level of similarity between the title, topic, and the abstract of the thesis of the students compared with the data of the thesis advisor in the form of advisor skill and thesis that has been guided by the advisor. Then the Cosine Similarity method will calculate the similarity level of the two queries. Total score similarity is derived from the sum of the cosine title value multiplied by the composition of the title, topic multiplied by the composition of the topic, and abstract multiplied abstract composition. The highest similarity value will be raised as a recommended advisor. The system has been built is a recommendation system that can assist the coordinator of the final task in the distribution of thesis advisor. In addition, the recommendation system of thesis advisor by applying Cosine Similarity method helps the students to get the advisor in accordance with the thesis proposed. Based on the system implementation, the system test was successful, and the precision and recall testing had average performance of 0.74 and 1 .
\end{abstract}

Keywords: Recommendation system, thesis advisor, cosine similarity

\section{Pendahuluan}

Penelitian tugas akhir adalah suatu karya ilmiah berdasarkan kegiatan mandiri mahasiswa yang membahas suatu masalah yang sesuai dengan bidang ilmu pada program studi yang ditempuh oleh mahasiswa tersebut. Penelitian tugas akhir merupakan salah satu syarat kelulusan yang ada di setiap perguruan tinggi jenjang Strata 1 (S1). Begitu pula pada Jurusan Teknik Informatika Unissula. Proses pelaksanaan tugas akhir dilakukan selama satu tahun (2 semester) yaitu pada tahun tingkat akhir. Dalam proses pelaksanaan tugas akhir di Jurusan Teknik
Informatika terdapat maksimal 2 orang dosen pembimbing dan 3 orang dosen penguji. Mahasiswa akan melakukan bimbingan dengan dosen pembimbing tugas akhir selama proses pengerjaan tugas akhir. Dosen pembimbing tugas akhir memiliki peran penting karena memiliki tanggung jawab untuk memastikan bahwa mahasiswa mampu menyusun tugas akhir dengan baik hingga tugas akhir tersebut siap diujikan dan berkualitas. Selain itu, dosen pembimbing sebaiknya merupakan orang yang menguasai bidang yang sesuai dengan tugas akhir mahasiswa sehingga proses bimbingan dapat berjalan dengan baik. 
Penentuan dosen pembimbing di program studi dilakukan oleh koordinator tugas akhir. Dalam penentuannya masih banyak yang menggunakan cara konvensional dengan mengandalkan pengetahuan pribadi tentang spesifikasi dosen yang dibutuhkan. Hal ini membutuhkan waktu yang cukup lama yaitu sekitar 2 minggu sampai satu bulan, apalagi jika terdapat banyak tugas akhir yang diajukan mahasiswa Teknik Informatika.

Masalah lain dari penentuan dengan cara konvensional oleh koordinator tugas akhir yaitu dosen pembimbing yang tidak sesuai dengan topik tugas akhir yang diajukan mahasiswa karena semua keputusan ada pada koordinator tugas akhir dimana dosen yang ditunjuk sebagai dosen pembimbing seusai atau tidak dengan topik tugas akhir yang diajukan. Selain itu, jumlah bidang peminatan mahasiswa dari tahun ke tahun berbeda sehingga jumlah dosen pembimbing dalam satu keahlian ada yang berlebih dan ada yang tidak cukup. Sehingga jika pembimbing tugas akhir tidak cukup dari satu keahlian dosen maka akan diambil dari dosen dengan keahlian lain sehingga banyak yang tidak sesuai dengan kompetensi tugas akhir yang diajukan mahasiswa.

Dari beberapa masalah yang telah dijabarkan di atas, dibutuhkan suatu metode yang perlu diterapkan untuk menyelesaikan masalah penentuan dosen pembimbing tugas akhir pada Jurusan Teknik Informatika Unissula. Salah satu metode yang dapat digunakan adalah dengan penerapan Cosine Similarity Matching. Cosine Similarity Matching merupakan metode yang digunakan untuk mengukur kemiripan antar dokumen atau teks [1]. Metode Cosine Similarity ini menghitung relevansi query dengan dokumen. Semakin besar nilai relevansi, maka query dan dokumen semakin relevan. Ada beberapa jenis similaritymeasure seperti Dice Coeficient, Jaccard Coeficient, Cosine Similarity, Euclidean Distance dan lainlain.Dalam tugas akhir ini menggunakan Cosine Similaritykarena tingakat error yang rendah dan dapat memberikan akurasi yang tinggi.Pada metode Cosine Similarity tidak melihat dari panjang pendeknya dokumen melainkan dari nilai term masing - masing [2].

Beberapa penelitian mengenai penentuan dosen pembimbing tugas akhir telah dilakukan di antaranya oleh Abu Salam, Verdian Putra Wicaksana, dan Khafiizh Hastuti dengan judul Sistem Rekomendasi Dosen Pembimbing Tugas Akhir dengan Menggunakan Algoritma Rabirn-Karp yaitu algoritma untuk mencocokan pola string antara topik tugas akhir mahasiswa dengan judul penelitan yang telah dilakukan oleh setiap dosen pembimbing [3]. Selain itu, terdapat penelitian tentang Sistem Rekomendasi Dosen Pembimbing Skripsi dengan Penerapan Algoritma Winnowing pada Universitas Jember yang dilakukan oleh Jarwati. Algoritma Winnowing merupakan konsep stringmatching untuk mencocokkan suatu string dengan string lainnya menggunakan teknik hashing. Pencocokan dapat dilakukan dengan menghitung similarity dari kunci penelitian dosen dan kata kunci topik skripsi yang dibandingkan [4]. Kemudian dalam Conference Paper ABEC tahun 2015 yang dilakukan oleh Gunawan, Indah Lestari, dan Muhammad Ihsan Zul dengan judul Sistem Pendukung Keputusan Pemilihan Dosen Pembimbing dan Penguji Proyek Tugas Akhir di Politeknik Caltex Riau menggunakan metode-metode Text Mining, k-Nearest Neighbor (k-NN), dan Simple Additive Weighting (SAW). Text mining untuk melakukan preprocessing data, k-NN untuk melakukan pengklasifikasian KBK (Klasifikasi Bidang Keminatan), sementara SAW untuk melakukan pembobotan kriteria dosen. Penelitian ini dapat merekomendasikan 5 nama dosen yang memiliki bobot tertinggi untuk menjadi pembimbing dan penguji PA berdasarkan KBK judul PA mahasiswa [5].

Pada penelitian ini, parameter variabel yang digunakan adalah data dosen, data mahasiswa, bidang keahlian dosen, judul tugas akhir dan abstrak yang pernah dibimbing oleh dosen, judul tugas akhir, topik tugas akhir, dan abstrak tugas akhir mahasiswa. Sehingga diharapkan dengan adanya metode Cosine Similarity Matching dapat membantu koordinator tugas akhir dalam menentukan dosen pembimbing tugas akhir, dosen dalam mendapatakan topik tugas akhir mahasiswa yang sesuai bidang keahliannya, dan mahasiswa dalam mendapatakan dosen pembimbing sesuai dengan topik tugas akhir yang diajukan.

\section{Metode \\ 2.1. Metode Pengumpulan Data}

Metode yang digunakan untuk pengumpulan data dalam tugas akhir ini adalah studi pustaka dan wawancara. Metode wawancara dilakukan dengan mewawancarai kordinator tugas akhir.

\subsection{Metode Perhitungan Cosine Similarity dalam Penentuan Dosen Pembimbing Tugas Akhir}

Proses penentuan dosen pembimbing dilakukan dengan cara mencocokkan antara query tugas akhir mahasiswa (judul, topik, dan abstrak) dengan data dosen pembimbing yang ada pada database. Berikut prosesnya ditunjukkan dalam bentuk flowchart.

Sebelum menghitung nilai kemirpa anatra query tugas akhir mahasiswa dan query dosen pembimbing dilakukan tahap preprocessing terlebih dahulu. Tahap preprocessing meliputi:

1. Case Folding yaitu tahap mengubah semua huruf dalam dokumen menjadi huruf kecil dan karakter selain huruf akan dihilangkan [6].

2. Tokenizing/Parsing adalah tahap pemecahan kalimat menjadi kata-kata tunggal atau frase-frase (Parsing) [7]. 
3. Stopwords Removal adalah tahap mengambil kata-kata penting dari hasil tahap tokenizing/parsing. Proses Stopwords Removal dilakukan dengan menghilangkan stoplist/stopword. Stopword dapat berupa kata penghubung, kata ganti, preposisi, dan lain-lain seperti kata "dan", "atau”, “dia", "di”, “yang”, "dari” dan lainlain [6].

4. Stemming adalah tahap transformasi suatu kata menjadi kata dasarnya (root word) [6].

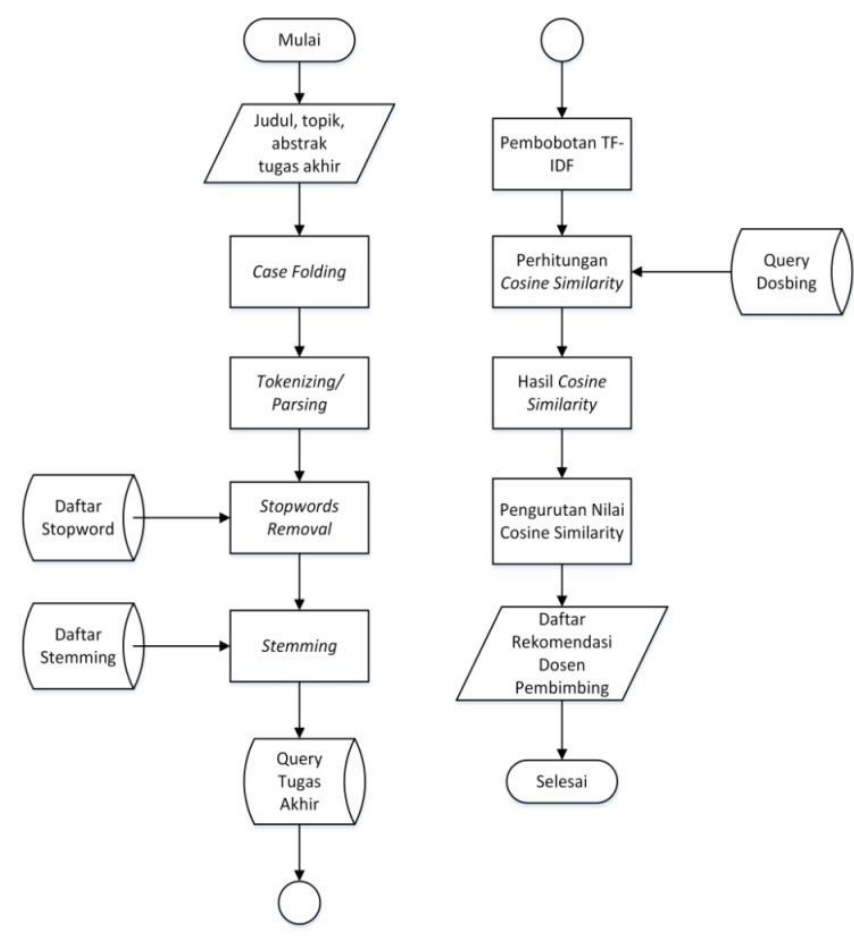

Gambar 1. Flowchart perhitungan cosine similarity

Setelah tahap preprocessing dilakukan pembobotan terhadap setiap term (kata) dari hasil prepocessing. Pembobotan yang digunakan dalam sistem ini adalah pembobotan TF-IDF. TF-IDF adalah metode pembobotan yang menggabungkan metode $T F$ (Term Frequency) dan IDF (Inverse Document Frequency) [8]. Pembobotan TFIDF dapat dihitung dengan menggunakan persamaan (2):

$$
\begin{aligned}
& \text { idf }=\log (\mathrm{n} / \mathrm{df}) \\
& \mathrm{w}=\mathrm{tf} \mathrm{x} \text { idf }
\end{aligned}
$$

Dimana $n$ merupakan jumlah seluruh dokumen yang digunakan, $d f$ (Document Frequency) adalah banyaknya kalimat yang berisi term dalam kumpulan dokumen, dan logdigunakan untuk memperkecil pengaruh terhadap relative tf [9].
Secara umum sistem yang dibangun menggunakan metode Cosine Similairity yaitu untuk menghitung similarity (tingkat kesamaan) antar dua buah objek (misalkan D1 dan D2) yang dinyatakan dalam dua buah vector dengan menggunakan keyword (kata kunci) dari sebuah dokumen sebagai ukuran [7]. Ketika dua dokumen identik, sudutnya adalah nol derajat $\left(0^{\circ}\right)$ dan kesamaannya adalah satu (1), dan ketika dua dokumen tidak identik sama sekali, sudutnya adalah 90 derajat $\left(90^{\circ}\right)$ dan kesamaannya adalah nol (0). Hal ini berarti apabila cos nilainya mendekati 1 , maka similaritynya semakin baik, sebaliknya jika mendekati 0 maka similaritynya semakin buruk [6]. Untuk menghitung nilai kesamaan dengan Cosine Similarity menggunakan persamaan (3):

Similarity $=\cos (\mathrm{A}, \mathrm{B})$

$$
=\frac{\sum_{i=1}^{i} A_{i} B_{i}}{\sqrt{\sum_{i=1}^{i} A_{i}^{2} \cdot \sum_{i=1}^{i} B_{i}^{2}}}
$$

Dimana A dan B adalah dokumen berbeda, $A_{i}$ adalah term $i$ yang ada pada dokumen $\mathrm{A}$ dan $B_{i}$ adalah term $i$ yang ada pada dokumen B [10].

\subsection{Metode Pengembangan Sistem}

Metode yang digunakan untuk pengembangan sistem pada tugas akhir ini adalah menggunakan System Development Life Cycle (SDLC) model Modified Waterfall yang merupakan pengembangan dari model Waterfall, dimana setiap tahap pengembangan dapat dilakukan peninjauan kembali terhadap tahap sebelumnya. Tahapan-tahapan pengembangan sistem dengan menggunakan model Modified Waterfall ditunjukkan pada gambar 2:

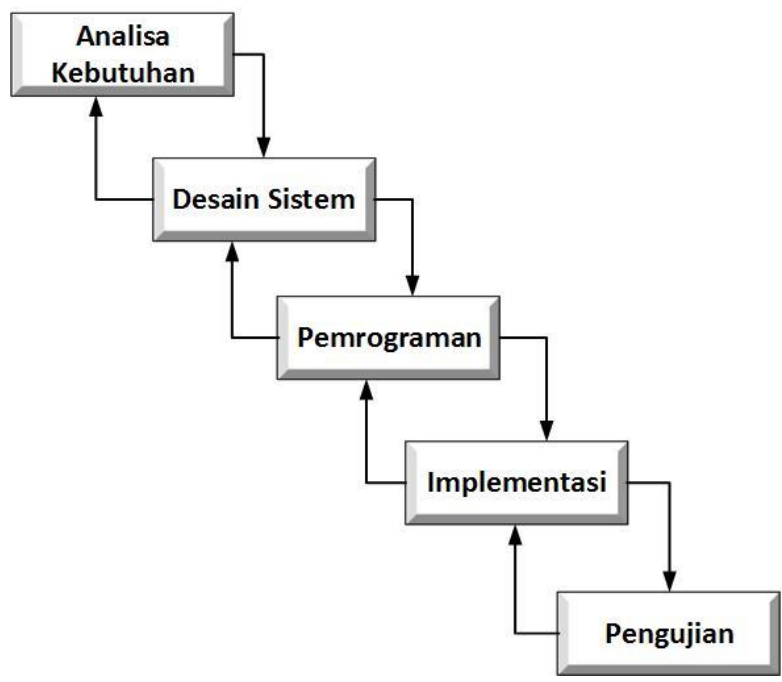

Gambar 2. Metode pengembangan sistem waterfall 


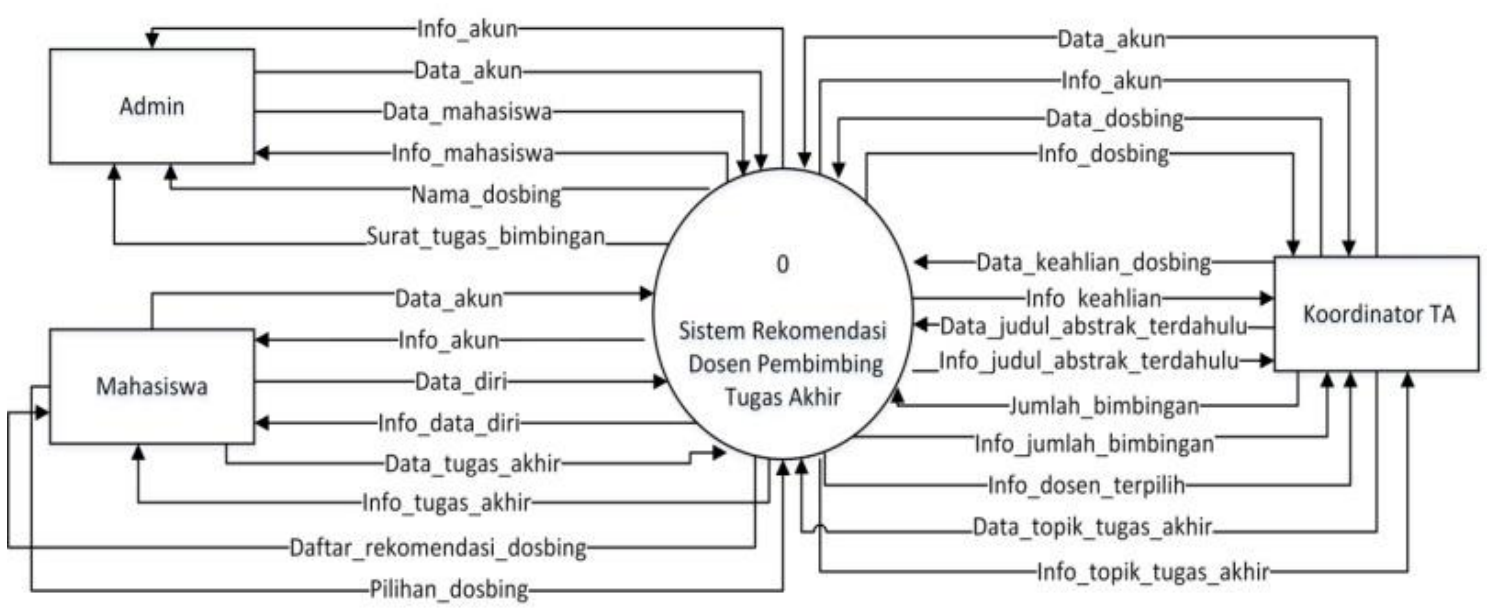

Gambar 3. Diagram konteks system

\section{Perancangan Sistem \\ 3.1. Diagram Konteks Sistem}

Gambar 3 merupakan diagram konteks dari sistem yang akan dibangun. Terdiri dari 3 entitas yaitu Admin, Koordinator TA, dan Mahasiswa. Masing - masing entitas harus login terlebih dahulu untuk dapat melakukan aktivitas di dalam sistem. Admin bertindak sebagai pengelola akun data user dan mengelurkan surat tugas bimbingan untuk dosen yang ditunjuk oleh Koordinator TA. Koordinator TA bertugas mengelola data dosen pembimbing tugas akhir termasuk data keahlian dosen pembimbing, data judul dan abstrak tugas akhir yang pernah dibimbing oleh dosen pembimbing yang bersangkutan. Koordinator TA juga bertugas untuk menyetujui atau memberikan rekomendasi dosen pembimbing lain yang diajukan mahasiswa. Mahasiswa akan menginputkan judul tugas akhir, abstrak, dan memilih topik tugas akhir. Kemudian sistem akan memberikan daftar rekomendasi dosen pembimbing (dosbing) berdasarkan hasil query tugas akhir mahasiswa tersebut.

\section{Hasil dan Analisa 4.1. Konsep Sistem}

Gambar 4 merupakan konsep sistem yang dibangun. Admin mengelola data user (mahasiswa dan koordinator TA). Koordinator TA dapat mengelola data dosen, bidang keahlian dosen, judul bimbingan tugas akhir terdahulu, topik tugas akhir, dan jumlah beban bimbingan dosen.Mahasiswa menginputkan judul tugas akhir, topik tugas akhir, dan abstrak tugas akhir ke dalam sistem. Kemudian sistem akan memproses inputan (query tugas akhir) dari mahasiswa dengan membandingkannya data tugas akhir terdahulu dan keahlian dosen sehingga diperoleh daftar rekomendasi nama dosen pembimbing. Mahasiswa dapat memilih maksimal 2 orang dosen pembimbing dari 5 nama yang direkomendasikan sistem. Selain itu admin dapat mencetak surat tugas bimbingan yang ditujukan kepada dosen pembimbing tugas akhir berdasarkan 2 dosen pilihan mahasiswa

\subsection{Hasil Rekomendasi}

Berikut ini adalah contoh perhitungan menggunakan metode Cosine Similarity. Jika dimisalkanquery yang diinputkan mahasiswa adalah:

a. Judul tugas akhir= Sistem Informasi Penjualan Mebel Berbasis Web

b. Topik tugas akhir $=$ Sistem Informasi

c. Abstrak $=$ Sistem informasi penjualan mebel terkomputerisasi untuk penjualan dan pembelian mebel berbasis web

Data query di atas akan dibandingkan dengan data dosen pembimbing (dosbing) dalam database. Diketahui terdapat 3 data dosen pembimbing yaitu:

a. Data Dosbing 1:

1. Judul tugas akhir yang pernah dibimbing= Penerapan Standar Metadata Dublin Core dalam Pengembangan Sistem Repositori Perpustakaan

2. Bidang keahlian $=$ Sistem Informasi

3. Abstrak= Penerapan metadata dublin core adalah pengembangan sistem repositori pustaka

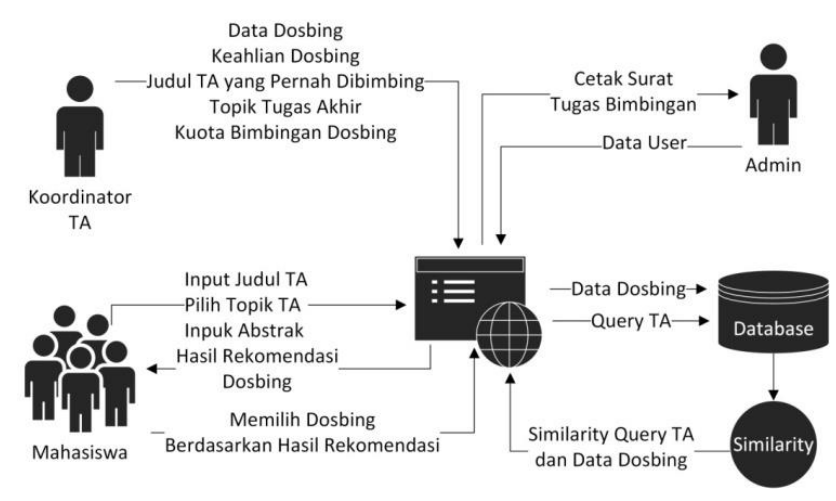

Gambar 4. Konsep Sistem 
b. Data Dosbing 2:

1. Judul tugas akhir yang pernah dibimbing= Implementasi Framework Laravel pada Sistem Informasi Penjualan dan Pembelian Mebel CV Rahmat

2. Bidan keahlian= Data Mining, Sistem Informasi, Database

3. Abstrak = Sistem informasi penjualan dan pembelian mebel bertujuan untuk memudahkan pelanggan dalam memesan mebel pada CV. Rahmat

c. Data Dosbing 3:

1. Judul tugas akhir yang pernah dibimbing $=$ Sistem Rekomendasi Pencarian Artikel Menggunkan Metode Jaccards Coeficient Berbasis Web

2. Bidang keahlian $=$ Sistem Informasi, Sistem Pakar

3. Abstrak $=$ Sistem rekomendasi pencarian artikel menggunakan metode Jaccards Coeficient berbasis web

Maka selanjutnya mencari data yang relevan dengan query yang diinputkan di atas, yaitu dengan membandingkan judul tugas akhir mahasiswa dengan data judul tugas akhir yang pernah dibimbing dosen, topik tugas akhir mahasiswa dengan data keahlian yang dimiliki dosen, dan abstrak akan dibandingkan dengan abstrak tugas akhir yang pernah dibimbing dosen. Adapun keterangannya sebagai berikut:
a. $\mathrm{Q}=$ Query yang dimasukkan
b. $\mathrm{D} 1=$ Data Dosbing 1
c. D2 = Data Dosbing 2
d. D3 = Data Dosbing 3

Hasil akhir rekomendasi dosen pembimbing tugas akhir didapatkan dari penjumlahan bobot tugas akhir, bobot topik tugas akhir, dan abstrak tugas akhir. Hasil akhir ditunjukkan pada tabel 1 .

Tabel 1. Hasil akhir rekomendasi

\begin{tabular}{ccccc}
\hline No. & Data Dosen & Judul TA & Topik TA & Abstrak \\
\hline 1 & D1 & 0 & 1 & 0 \\
2 & D2 & 0.258 & 0.093 & 0.119 \\
3 & D3 & 0.163 & 0.306 & 0.183 \\
\hline
\end{tabular}

Berdasarkan data pada tabel 1 total score cosine similarity untuk rekomendasi dosen pembimbing tugas akhir dihitung dengan rumus:

Total Score rekomendas $\mathrm{i}=($ Komposisi judul $\mathrm{x}$ hasil cosine judul $)+($ Komposisitopik $\mathrm{x}$ hasil cosine topik $)+($ Komposisi abstrak $\mathrm{x}$ hasil cosine abstrak)

Misal nilai komposisi yang diberikan adalah:
a. Komposisi judul
$30 \%$ atau 0.3
b. Komposisi topik : $\quad 40 \%$ atau 0.4
c. Komposisi abstrak : $30 \%$ atau 0.3

Sehingga dapat diketahui total score dosen pembimbing yangdirekomendasikan sistem adalah sebagai berikut:

$$
\begin{aligned}
\text { a. } \mathrm{D} 1 & =(0.3 \times 0)+(0.4 \times 1)+(0.3 \times 0) \\
& =0.4 \\
\text { b. } \mathrm{D} 2 & =(0.3 \times 0.258)+(0.4 \times 0.093)+(0.3 \times 0.119) \\
& =0.15 \\
\text { c. } \mathrm{D} 3 & =(0.3 \times 0.163)+(0.4 \times 0.306)+(0.3 \times 0.183) \\
& =0.226
\end{aligned}
$$

Kesimpulan berdasarkan perhitungan di atas diketahui bahwa dokumen D1(Data Dosbing 1) memiliki tingkat kemiripan yang paling tinggi dengan query $(\mathrm{Q})$ yaitu 0.4 .

\subsection{Implementasi Sistem}

Berikut adalah implementasi sistem rekomendasis dosen pembimbing tugas akhir. Gambar 5 merupakan halaman pilih dosen pembimbing. Pada halaman ini mahasiswa mengisi judul tugas akhir, memilih topik tugas akhir dan mengisiabstrak tugas akhir. Kemudian dari hasil proses data tugas akhir mahasiswa akanmenghasilkan rekomendasi dosen pembimbing seperti ditunjukkan gambar 6.

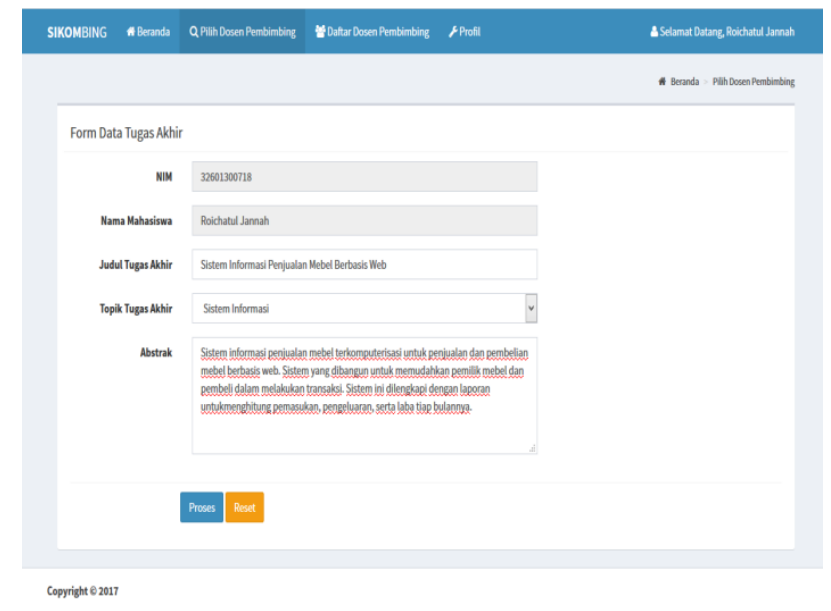

Gambar 5. Halaman pilih soesn pembimbing

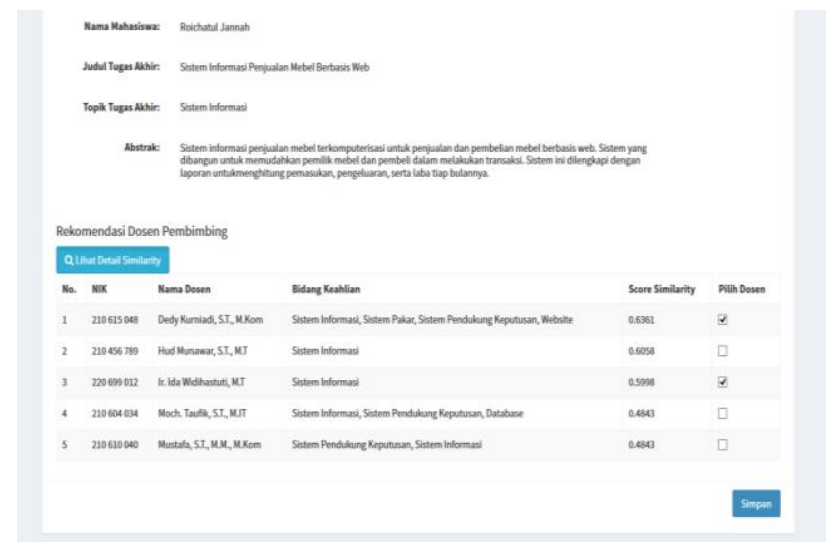

Gambar 6. Halaman daftar rekomendasi pembimbing 
Gambar 6 merupakan halaman rekomendasi dosen pembimbing yang diberikan oleh sistem berdasarkan query tugas akhir yang diinputkan seperti yang ditunjukkan pada gambar 5. Pada halaman rekomendasi dosen pembimbing mahasiswa memilih dua orang dosen untuk diajukan sebagai dosen pembimbing.

\subsection{Pengujian}

Pada pengujian algoritma precision dan recall dilakukan dengan 3 kali percobaan yaitu percobaan 1, percobaan 2 , dan percobaan 3 dimana setiap percobaan diuji dengan query tugas akhir yang berbeda. Hal ini untuk melihat nilai akurasi dari pemeberian rekomendasi dosen pembiming tugas akhir. Berikut adalah percobaan yang dilakukan:

1. Percobaan 1

Pada percobaan 1 digunakan querypada tabel 2.

Tabel 2. Percobaan 1 (precision dan recall)

\begin{tabular}{lllr}
\hline Judul Tugas Akhir & Topik & Abstrak & \\
\hline Rancang Bangun & Sistem & Sistem yang dibangun \\
Sistem Informasi & Informasi & bertujuan untuk mengelola \\
Penerimaan & & penerimaan mahasiswa \\
Mahasiswa Baru & & baru & secara \\
& & terkomputerisasi. Sistem \\
& & dibangun berbasis web. \\
\hline
\end{tabular}

Berdasarkan query pada Tabel 2, ditunjukkan bahwa jumlah dokumen relevan yang dikembalikan sebanyak 10 dokumen, dokumen yang tidak relevan dan dikembalikan sebanyak 3 dokumen, untuk jumlah dokumen relevan yang tidak dikembalikan sebanyak 0 dokumen. Maka, nilai precision dan recall untuk query pada tabel 2 adalah:

Precision $=10 /(10+3)=10 / 13=0.77$

Recall $\quad=10 /(10+0)=10 / 10=1$

2. Percobaan 2

Pada percobaan 2 digunakan query pada tabel 3.

Tabel 3. Percobaan 2 (precision dan recall)

\begin{tabular}{|c|c|c|}
\hline Judul Tugas Akhir & Topik & Abstrak \\
\hline $\begin{array}{lr}\text { Sistem } & \text { Informasi } \\
\text { Penjualan } & \text { Mebel } \\
\text { Berbasis Web } & \end{array}$ & $\begin{array}{l}\text { Sistem } \\
\text { Informasi }\end{array}$ & $\begin{array}{l}\text { Sistem informasi penjualan } \\
\text { mebel terkomputerisasi untuk } \\
\text { penjualan dan pembelian } \\
\text { mebel berbasis web. Sistem } \\
\text { yang dibangun untuk } \\
\text { memudahkan pemilik mebel } \\
\text { dan pembeli dalam melakukan } \\
\text { transaksi. Sistem ini dilengkapi } \\
\text { dengan laporan untuk } \\
\text { menghitung pemasukan, } \\
\text { pengeluaran, serta laba tiap } \\
\text { bulannya. }\end{array}$ \\
\hline
\end{tabular}

Berdasarkan query pada tabel 3 ditunjukkan bahwa jumlah dokumen relevan yang dikembalikan sebanyak 9 dokumen, dokumen yang tidak relevan dan dikembalikan sebanyak 4 dokumen, untuk jumlah dokumen relevan yang tidak dikembalikan sebanyak 0 dokumen. Maka, nilai precision dan recall untuk query pada tabel 3 adalah:

$\begin{array}{ll}\text { Precision } & =9 /(9+4)=9 / 13=0.69 \\ \text { Recall } & =9 /(9+0)=9 / 9=1\end{array}$

3. Percobaan 3

Pada percobaan 3 digunakan query pada tabel 4 .

Tabel 4. Percobaan 3 (precision dan recall)

\begin{tabular}{|l|l|l|}
\hline Judul Tugas Akhir & Topik & Abstrak \\
\hline Implementasi & Pengolahan & Aplikasi yang dibangun \\
Algoritma LZW untuk & Citra & bertujuan untuk \\
Kompresi File Video & & melakukan kompresi \\
Berormat Avi & & terhadap video yang \\
Menggunakan & & berformat dengan \\
MATLAB & & menggunakan algoritma \\
& & LZW. Aplikasi dibangun \\
& & dengan menggunakan \\
& & MATLAB. \\
\hline
\end{tabular}

Berdasarkan query pada tabel 4 Ditunjukkan bahwa jumlah dokumen relevan yang dikembalikan sebanyak 10 dokumen, dokumen yang tidak relevan dan dikembalikan sebanyak 3 dokumen, untuk jumlah dokumen relevan yang tidak dikembalikan sebanyak 0 dokumen. Maka, nilai precision dan recall untuk query pada tabel 4 adalah:

$\begin{array}{ll}\text { Precision } & =10 /(10+3)=10 / 13=0.77 \\ \text { Recall } & =10 /(10+0)=10 / 10=1\end{array}$

Berdasarkan pengujian yang telah dilakukan, maka diambil kesimpulan yang ditunjukkan pada Tabel 5.

Tabel 5. Nilai rata-rata precision dan recall

\begin{tabular}{ccc}
\hline Percobaan & Precision & Recall \\
\hline I & 0.77 & 1 \\
II & 0.69 & 1 \\
III & 0.77 & 1 \\
Nilai rata-rata & 0.74 & 1 \\
\hline
\end{tabular}

\section{Kesimpulan}

Kesimpulan yang dapat ditarik dari hasil perancangan, implementasi, dan pengujian sistem yaitu Cosine Similarity dapat diimplementasikan dalam sebuah sistem yang dapat menjadi media rekomendasi dosen pembimbing tugas akhir. Hal ini ditunjukkan dengan pengujian sistem yang dilakukan memperoleh performa yang cukup baikyaitu hasil pengujian precision dan recall memiliki performa rata-rata 0.74 dan 1. Dengan demikiansistem yang telah dibangun dapat membantu Koordinator Tugas Akhir dalam pendistribusian dosen pembimbing tugas akhir. Diharapkan sistem rekomendasi dosen pembimbing tugas akhir dengan menerapkan metode Cosine Similarity membantu mahasiswa mendapatkan dosen pembimbing sesuai dengan tugas akhir yang diajukan. 


\section{Referensi}

[1]. S. Christina, "Kinerja Cosine Similarity dan Semantic Similarity dalam Pengidentifikasian Relevansi Nomor Halaman pada Daftar Indeks Istilah,” di Sentika, 2014.

[2]. M. Fachrurrozi, M. Fachrurrozi, and A. A. Manik, "Perbaikan Ejaan Kata pada Dokumen Bahasa Indonesia dengan Metode Cosine Similarity Perbaikan Ejaan Kata pada Dokumen Bahasa Indonesia dengan Metode Cosine Similarity", Seminar Nasional Rekayasa Komputer dan Aplikasinya, Universitas Andalas, 2016.

[3]. A. Salam, V. P. Wicaksana, and K. Hastuti, "Sistem Rekomendasi Penentuan Dosen Pembimbing Tugas Akhir dengan Menggunakan Algoritma Rabin-Karp," Techno.COM, vol. 14, no. 3, hal. 225-233, 2015.

[4]. Jarwati, A.C. Prihandoko, W.E. Yulia R , "Penerapan Algoritma Winnowing pada Sistem Rekomendasi Penetuan Dosen Pembimbing Skripsi (Studi Kasus: Prodi Sistem Informasi)," BERKALA SAINSTEK, vol. 5, no.1, hal. 11-20, 2017.
[5]. Gunawan, I. Lestari, and M. I. Zul, "Sistem Pendukung Keputusan Pemilihan Pembimbing dan Penguji Proyek Akhir di Politeknik Caltex Riau," in 3rd Applied Business and Engineering Conference, Batam, 17-18 Sept 2015.

[6]. R. V. Imbar, M. Ayub, and A. Rehatta, "Implementasi Cosine Similarity dan Algoritma Smith-Waterman untuk Mendeteksi Kemiripan Teks," J. Inform., vol. 10, hal. 3142, 2014.

[7]. O. Nurdiana, Jumadi, and D. Nursantika, "Perbandingan Metode Cosine Similarity dengan Metode Jaccard Similarity pada Aplikasi Pencarian Terjemah Al - Qur ' an," JOIN, vol. I, no. 1, hal. 59-63, 2016.

[8]. T. M. Akbar, A. P. Kurniati, M. A. Bijaksana, F. T. Informatika, and U. Telkom, "Analisis Perbandingan Metode Pembobotan Kata Tf.Idf dan Tf.Rf Terhadap Performansi Kategorisasi Teks," Tugas Akhir, Teknik Informatika, Universitas Telkom, 2012

[9]. W. Yulita, "Implementasi Metode Maximum Marginal Relevance pada Peringkasan Teks," Tugas Akhir, Universitas Negeri Semarang, 2015.

[10]. Sugiyamto, B. Surarso, and A. Sugiharto, "Analisa Performa Metode Cosine dan Jacard pada Pengujian Kesamaan Dokumen," J. Masy. Inform., vol. 5, no. 10, hal. 1-8, 2014. 